\title{
Population dynamics of the water mite Unionicola arcuata (Unionicolidae) in the freshwater bivalve Cristaria plicata (Unionidae) in Poyang Lake, eastern China
}

\author{
Chungen Wen ${ }^{1,2}, \mathrm{P} \mathrm{Nie}^{1, *}$, Zhimin $\mathrm{Zhu}^{2}$ \\ ${ }^{1}$ State Key Laboratory of Freshwater Ecology and Biotechnology and Laboratory of Fish Diseases, Institute of Hydrobiology, \\ Chinese Academy of Sciences, Wuhan, Hubei Province 430072, PR China \\ ${ }^{2}$ Department of Bioscience, Nanchang University, Nanchang, Jiangxi Province 330047, PR China
}

\begin{abstract}
Population dynamics of the water mite Unionicola arcuata were investigated in the freshwater bivalve Cristaria plicata during the period from January to December 2002 in Poyang Lake, East China. A pattern of seasonal variation was observed, with prevalence and abundance peaking in early spring and autumn. The number of mites in individual hosts was significantly correlated with the size, but not with the sex, of bivalves. The change in infection level of mites on different infection sites in C. plicata was significant, with $>58 \%$ of the mites found on the outer and inner gills, indicating that $U$. arcuata shows site preference.
\end{abstract}

KEY WORDS: Water mites $\cdot$ Unionicola arcuata $\cdot$ Freshwater bivalve $\cdot$ Cristaria plicata $\cdot$ Population dynamics

Resale or republication not permitted without written consent of the publisher

\section{INTRODUCTION}

Many unionicolid mites are parasites of freshwater bivalves in the family Unionidae and snails in the families Viviparidae and Ampullariidae (cf. Mitchell \& Pitchford 1953, Mitchell 1955, Davids 1973, Hevers 1978, 1980), while some others are free living and/or commonly associated with sponges (Cook 1974). These parasitic mites use bivalves as hosts for oviposition and metamorphosis (Mitchell 1955, Paterson \& Macleod 1979). The females lay eggs on the gills of the bivalve host, and the larvae normally hatch in spring and then leave the host to invade aquatic insects (Jones 1965, 1978, Böttger 1976, Hevers 1978, Edwards \& Dimock 1995). The larvae subsequently invade a bivalve host and form a quiescent transformational stage, the protonymph, in host gills. The sexually immature deutonymph emerges first, and the quiescent tritonymph and adult are normally found on the gills of the bivalve host (Baker 1977, Roberts et al. 1978).

In China, a large number of lakes are distributed in the lower and middle reaches of the Yangtze
River, and, in these lakes, several species of freshwater bivalves occur (Zhang et al. 1986, Wen et al. 1996, Wen \& Zhu 1999), among which Cristaria plicata and Hyriopsis cumingii are of economical importance and are known as 'pearl bivalves' in the aquaculture industry of China. The water mite Unionicola arcuata (Wolcott) has been described in several species of freshwater bivalves in China and in other Asian countries, as well as in North America (Imamura 1953, Baker 1982, Vidrine 1986, Wen \& Zhu 1999), and has been reported as a parasite in the 'pearl bivalve' C. plicata both in lakes and under culture conditions for pearl production in China. Several other species in the family Unionicolidae have been the focus of ecological investigations (Humes \& Jamnback 1950, Conroy 1974, Gordon et al. 1979, Dimock 1985, Joy \& Hively 1990). However, relatively little is known about the population biology of the water mite $U$. arcuata. Hence, the present study was designed to investigate the population biology of $U$. arcuata in C. plicata in Poyang Lake, Jiangxi Province, eastern China. 


\section{MATERIALS AND METHODS}

Sample locality and sampling programme. Poyang Lake $\left(28^{\circ} 22^{\prime}\right.$ to $29^{\circ} 45^{\prime} \mathrm{N}$ and $115^{\circ} 47^{\prime}$ to $\left.116^{\circ} 45^{\prime} \mathrm{E}\right)$ is the largest freshwater lake in China and is located on the southern bank of the Yangtze River in Jiangxi Province. The northern part of the lake is a water channel joining the Yangtze River, with a length of $40 \mathrm{~km}$ and a width of 3 to $5 \mathrm{~km}$, and the southern part is the main lake, with a length of $173 \mathrm{~km}$ and a mean width of $16.9 \mathrm{~m}$ (maximum width being $74 \mathrm{~km}$ ). Its volume is 27.6 billion $\mathrm{m}^{3}$, holding water from 5 rivers and discharging into the Yangtze River. In this respect, Poyang Lake is a seasonal lake, and, in the dry season, the size of the lake shrinks to $<1000 \mathrm{~km}^{2}$, while in the rainy season, normally in late summer, its size may reach up to $4000 \mathrm{~km}^{2}$.

Monthly samples of Cristaria plicata were collected by hand or with a clam rake from the 25th to the 30th of each month between January and December 2002 in shallow water areas of the lake, and, on each occasion, the number of $C$. plicata obtained represented a $2 \mathrm{~d}$ effort. A total of 274 bivalves were examined, and bivalves were placed individually in separate plastic bags and brought back to a local experimental station, where the length of each bivalve was measured to the nearest millimetre with a caliper. Bivalves were then opened by severing the adductor muscle; their sex was determined by examining the shape of the outer gills. Mites of various developmental stages were counted separately at different sites on the bivalves, i.e. on the mantle, outer gill, inner gill, podium, lip, inhalant siphon, between the mantle and outer gill, between the outer gill and inner gill, and between the inner gill and podium. Eggs of mites were not included, as the number of eggs was rather high in spring and eggs covered almost the entire mantle and gills.

Statistical analyses. To test if monthly change in prevalence was significant, a $G$-test of heterogeneity was employed, and 1-way analysis of variance (ANOVA) was used to test whether monthly change in abundance was significant. A previous investigation showed that the size of bivalves was associated with the number of mites (Dimock 1985). Thus, the bivalves examined were divided into 6 length groups (see Fig. 2), and the relationships between the length group and abundance and also between the number of mites and the lengths of individual bivalves were analysed by Spearman's rank correlation. Differences in abundance between female and male bivalves were tested using Student's $t$-test. A $G$-test of heterogeneity was also used to test variations in prevalence of the mites on different infection locations in the host. All statistical methods were carried out according to Sokal \& Rohlf (1981).

\section{RESULTS}

\section{Prevalence levels of Unionicola arcuata}

The water mite Unionicola arcuata occurred throughout the year in the bivalve Cristaria plicata, with an overall prevalence of $67.88 \%$ and abundance of $20.20 \pm$ 38.45 (mean $\pm \mathrm{SD}$ ) for all samples pooled. The prevalence level of $U$. arcuata was high in late winter and early spring and again autumn (Fig. 1), with the highest level being $100 \%$ in February and October. A lower level of prevalence was observed in summer, with the lowest level being $27 \%$ in June. Change in prevalence was significantly seasonal $\left(G=444.78>\chi_{0.001}^{2}=22.46\right.$. $\mathrm{df}=11,<0.001)$. The pattern of changes in abundance was similar, with higher abundance levels observed in spring and autumn, $(38.57 \pm 28.86$ and $65.95 \pm 80.59$, respectively; Fig. 1). A lower level of abundance was observed in summer, being $0.27 \pm 0.62$ in June. Statistical analysis revealed that the change in abundance was also significantly seasonal (ANOVA, $\mathrm{p}<0.05$ ).

\section{Correlation between the number of Unionicola arcuata and the length of Cristaria plicata}

The correlation between the number of mites and the length of individual bivalves was significant (Spear-
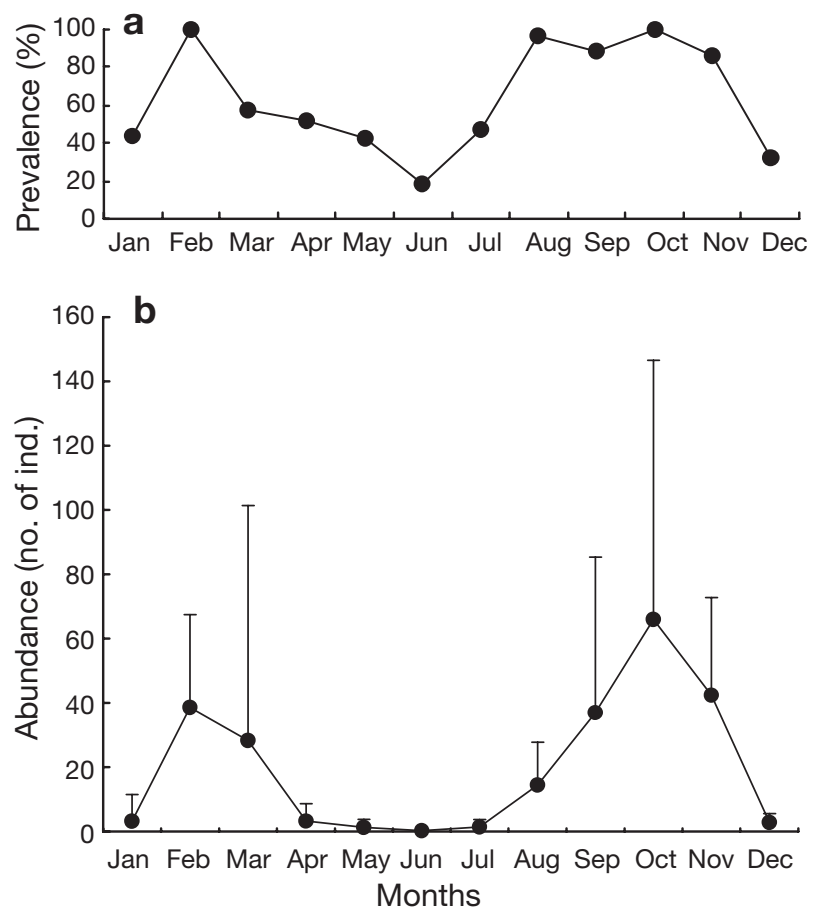

Fig. 1. Unionicola arcuata in Cristaria plicata. Monthly changes in the (a) prevalence and (b) abundance (mean $+\mathrm{SD}$ ) of the water mite in the pearl bivalve 


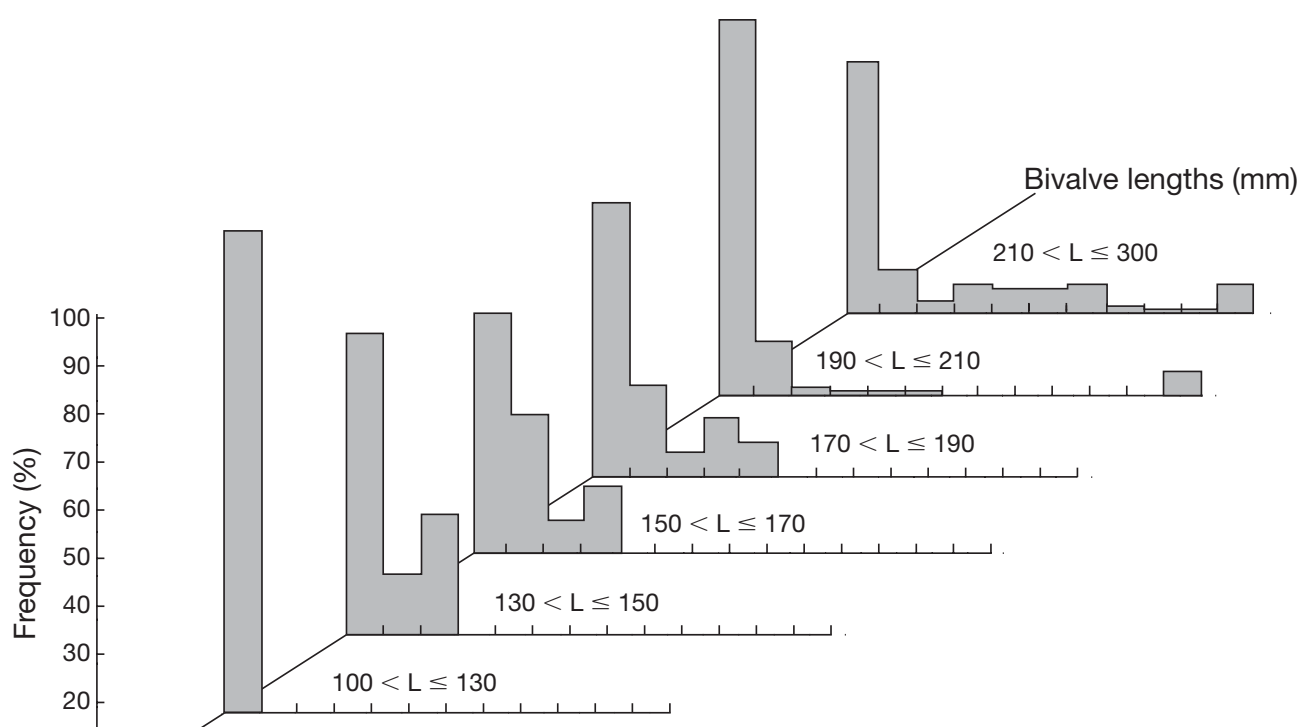

man's $r=0.21, \mathrm{df}=273, \mathrm{p}<0.05)$, and a significant relationship was also observed between the abundance and the length groups (Spearman's $r=0.92$, $\mathrm{df}=5, \mathrm{p}<0.05)$. The prevalence in different length groups was also significantly different $(G=66.77>$ $\chi_{0.001}^{2}=22.46$. df $\left.=5,<0.001\right)$. Bivalves shorter than $130 \mathrm{~mm}$ had the least number of mites, with the abundance being $0.67 \pm 1.21$ (Fig. 2). However, larger bivalves harboured more mites, with abundance being $28.98 \pm 45.27$ in bivalves longer than $210 \mathrm{~mm}$.

\section{Difference in Unionicola arcuata infection between female and male bivalves}

The prevalence of Unionicola arcuata was $71.01 \%$ in 138 female bivalves and $63.97 \%$ in 136 males, with the abundances being $22.06 \pm 48.99$ and $18.56 \pm 44.97$, respectively. No significant difference was found in abundance between female and male bivalves $(t=$ 0.97, p > 0.05; Table 1). When female and male bivalves were considered separately in monthly samples, the prevalence of mites also showed an increase in early spring and autumn, with highest prevalence being $100 \%$ in February and October, and abundances being $47.76 \pm 34.06$ and $23.63 \pm 9.87$ in February and $103.38 \pm 91.98$ and $60.33 \pm 29.29$ in October for females and males, respectively. Again, decrease was also observed in summer, with the lowest level of prevalence being 18.18 and $18.25 \%$ in June, and abundance at $0.18 \pm 0.41$ and $0.36 \pm 0.81$ also in June for females and males, respectively.
Fig. 2. Unionicola arcuata in Cristaria plicata. Frequency distribution of the water mite in relation to different lengths (L) of the pearl bivalve

\section{Gill preference by Unionicola arcuata}

When all samples were pooled, $58 \%$ of the mites were found on the outer gills, $59 \%$ were found on the inner gills and relatively low levels $(0.7 \%)$ appeared between the mantles and outer gills, on the lips and on inhalant siphons (Fig. 3).

\section{DISCUSSION}

The prevalence of Unionicola arcuata differed significantly from that of several other species in the genus Unionicola, for which seasonal fluctuation was not observed. Gordon et al. (1979) did not detect a sea-

Table 1. Unionicola arcuata in Cristaria plicata. Mean abundance $( \pm \mathrm{SD})$ of the water mite at different sites in females and males of the pearl bivalve (M: mantles; M-OG: between mantles and outer gills; OG: outer gills; O-IG: between outer gills and inner gills; IG: inner gills; IG-P: between inner gills and podium; P: podium; L: lip; IS: inhalant siphon)

\begin{tabular}{|lll|}
\hline & C. plicata (o) & C. plicata $\left(\right.$ ( $\left.^{\text {' }}\right)$ \\
\hline M & $2.667 \pm 6.685$ & $2.397 \pm 6.875$ \\
M-OG & $0.036 \pm 0.306$ & $0.014 \pm 0.202$ \\
OG & $7.471 \pm 17.953$ & $5.846 \pm 11.973$ \\
O-IG & $0.053 \pm 0.167$ & $0.045 \pm 0.201$ \\
IG & $7.986 \pm 14.447$ & $6.456 \pm 14.691$ \\
IG-P & $0.083 \pm 0.154$ & $0.053 \pm 0.102$ \\
P & $3.746 \pm 9.092$ & $3.706 \pm 10.544$ \\
L & $0.022 \pm 0.191$ & 0 \\
IS & 0 & $0.044 \pm 0.382$ \\
\hline
\end{tabular}




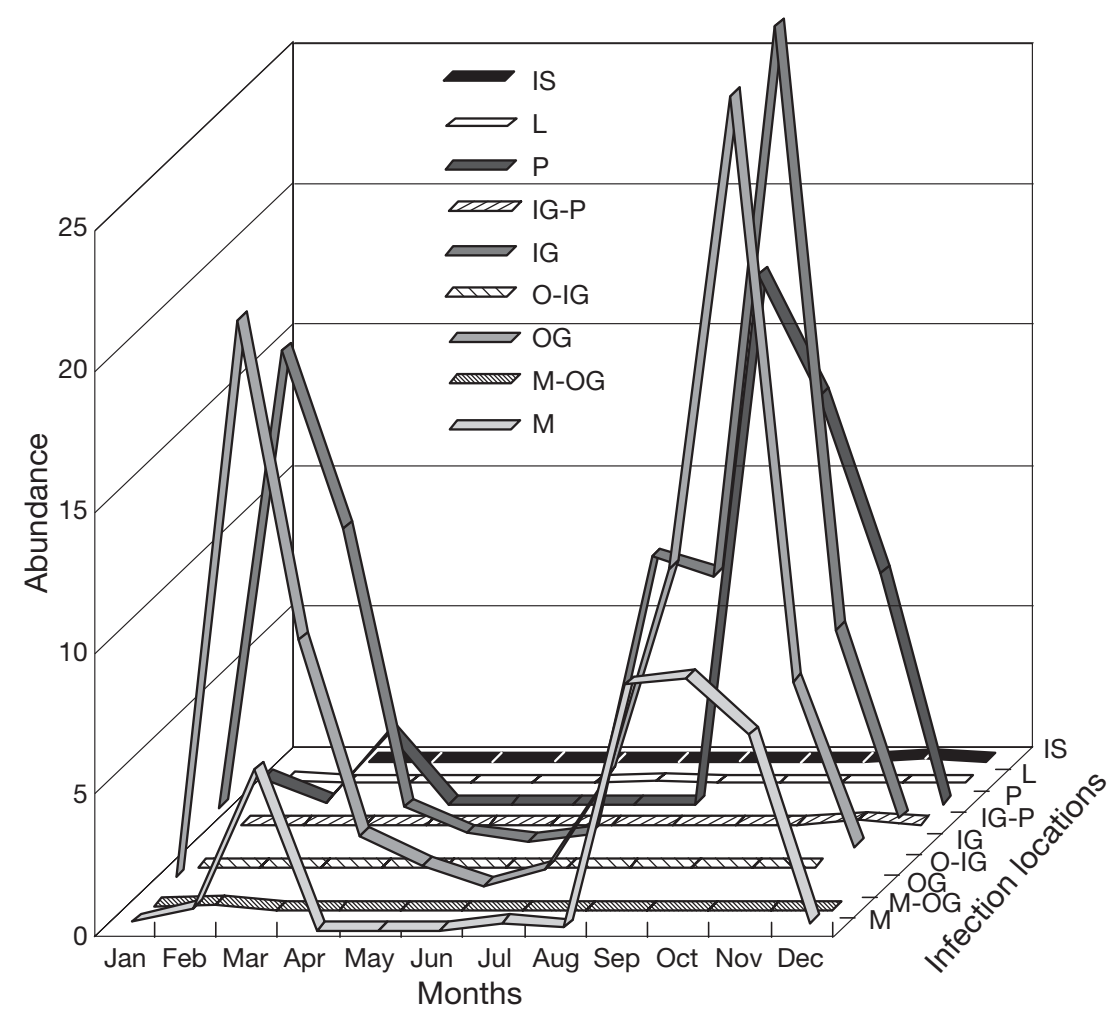

Fig. 3. Unionicola arcuata in Cristaria plicata. Monthly changes in abundance of the water mite at different sites on the pearl bivalve. Abbreviations for infection sites are as in Table 1

sonal change in the adult water mite $U$. formosa in Anodonta cataracta in Canada. However, Dimock (1985) reported that seasonal variation in $U$. formosa infection was obvious in $A$. imbecillis, with adult females being most numerous in winter and least numerous in late spring and summer, and that the seasonality in the distribution of males was only evident in the infrequent occurrence of multiple males present in its host mussels. For the unionicolid mite U. crassipes crassipes, the number of adults peaked in late summer and the larvae moved onto sponges in early June and in July (Conroy 1974). Dimock (1985) observed that oviposition of $U$. formosa occurred mainly in early spring, with all females being gravid, and, as oviposition progressed, the number of mites in bivalves decreased. The reproductive cycle of water mites may thus account for the observed seasonality in prevalence and abundance of $U$. arcuata in the bivalve Cristaria plicata in the present study. However, other factors, such as light and host behaviour, have been proposed as an explanation of the seasonal occurrence of water mites (Roberts et al. 1978), but whether this is the case for $U$. arcuata requires further investigation.

Population biology of water mites in the family Unionicolidae has been commonly observed in relation to bivalve size (Humes \& Jamnback 1950, Mitchell 1965,
Gordon et al. 1979, Dimock 1985). The prevalence of Najadicola ingens was reported to be related in reverse to the sizes of Elliptio complanata and Anodonta cataracta (Humes \& Jamnback 1950). However, no correlation was found between the size of Lampsilis siliquoidea and any parameters of the population biology of Unionicola fossulata (Mitchell 1965). Dimock (1985) found that the abundance of female $U$. formosa increased with the size of its host $A$. imbecillis. In fact, the rise in infection level of $U$. arcuata is always related to the size of Cristaria plicata. Larger and older bivalves may provide more space for the parasites, and more parasites may be recruited, resulting in a high level of infection, as observed in the present study.

Resident mites often display obvious site preferences (Mitchell 1965, Dimock 1985, Vidrine 1989, Joy \& Hively 1990, Vidrine \& Clark 1993). Adult mites of Unionicola ypsilophora and $U$. fossulata were most frequently found between the gills and, to a lesser extent, between the gills and the foot (Mitchell \& Pitchford 1953, Mitchell 1965, Baker 1982); U. formosa showed a preferred location with respect to the gill surface (Davids 1973, Gordon et al. 1979). The results obtained in the present study confirmed that $U$. arcuata has a strong site preference, with gills being the preferred parasitic site.

Bivalve mussels usually serve as hosts for freshwater mites in the genus Unionicola (Mitchell 1955, Davids 1973, Hevers 1980, Vidrine 1980). U. ypsilophora and $U$. bonzi spend part or all of their adult life in the mantle cavity of Anodonta cygnea and Unio pictorum (Davids 1973, Hevers 1980). Adults of U. intermedia and $U$. formosa were parasitic, piercing onto the gills of their hosts to ingest body fluids (Baker 1977), and host mucus, gill tissue, or haemolymph may also be consumed (Fisher et al. 2000). It will be of interest to investigate whether $U$. arcuata causes any pathological alterations in the pearl bivalve Cristaria plicata.

Acknowledgements. We thank Malcolm F. Vidrine, Tohru Uchida, Taiji Imamura, Kurt O. Viets, David Barr and Harry Smit for providing us with some of the literature. This research was financially supported by a project of the Key Scientific and Technological Programme and the Natural Science Foundation of Jiangxi Province, China, and partly by a project (No. 30025035) from National Natural Science Foundation of China. 


\section{LITERATURE CITED}

Baker RA (1977) Nutrition of the mite Unionicola intermedia Koenike and its relationship to the inflammatory response induced in its molluscan host Anodonta anatine L. Parasitology 75:301-308

Baker RA (1982) Unionicolid mites from central New York. NY Entomol Soc 90(3):176-180

Böttger K (1976) Types of parasitism by larvae of water mites (Acari: Hydrachnellae). Freshw Biol 6:497-500

Conroy JC (1974) The taxonomy and ecology of Unionicola crassipes (Müller), a water mite parasitic on the freshwater sponge, Spongilla lacustris (Linne), in Marion Lake, British Columbia. In: Piffl E (ed) Proceedings of the 4th International Congress of Acarology. Akademiai Kiado, Budapest, p 135-142

Cook DR (1974) Water mite genera and subgenera. Mem Am Entomol Inst 21:1-860

Davids C (1973) The relations between mites of the genus Unionicola and the mussels Anodonta and Unio. Hydrobiologia 41:37-44

Dimock RV Jr (1985) Population dynamics of Unionicola formosa (Acari: Unionicolidae), a water mite with a harem. Am Midl Nat 114:168-179

Edwards DD, Dimock RV Jr (1995) Life history characteristics of larval Unionicola (Acari: Unionicolidae) parasitic on Chironomus tentans. J Nat Hist 29:1197-1208

Fisher GR, Dimock RV Jr, Kuhn RE (2000) The symbiotic water mite Unionicola formosa (Acari: Unionicolidae) ingests mucus and tissue of its molluscan host. J Parasitol 86:1254-1258

Gordon MJ, Swan BK, Paterson CG (1979) The biology of Unionicola formosa (Dana and Whelpley): a water mite parasitic in the unionid bivalve, Anodonta cataracta (Say), in a New Brunswick Lake. Can J Zool 57:1748-1756

Hevers J (1978) Interspezifische Beziehungen zwischen Unionicola-Larven (Hydrachnellae, Acari) und Chironomidae (Diptera, Insecta). Verh Ges Oekol 7:211-217 (in German with English abstract)

Hevers J (1980) Biologisch-ökologische Untersuchungen zum Entwicklungszyklus der im Deutschland auftretenden Unionicola-Arten (Hydrachnellae, Acari). Arch Hydrobiol Suppl 57:324-373 (in German with English summary)

Humes AG, Jamnback HA (1950) Najadicola ingens (Koenike), a water-mite parasitic in fresh-water clams. Psyche 57: $77-87$

Imamura $\mathrm{T}$ (1953) Some stenophilous water-mites from Hyogo Prefecture. J Fac Sci Hokkaido Univ 11:261-276

Jones RKH (1965) Parasitism by larvae of Unionicola interme-

Editorial responsibility: Wolfgang Körting,

Hannover, Germany dia Koenike and another Unionicola sp. (Acarina: Pionae) on chironomids. Nature 207:317-318

Jones RKH (1978) Parasitism by Unionicola spp. larvae on chironomids. Hydrobiologia 60:81-87

Joy JE, Hively JW (1990) Population dynamics of adult Unionicola formosa (Acari: Hydracarina), a parasite of Anodonta imbecillis (Mllusca: Bivalvia), in West Virginia. Brimleyana 16:33-42

Mitchell RD (1955) Anatomy, life history, and evolution of the mites parasitizing freshwater mussels. Misc Publ Mus Zool Univ Mich 89:1-28

Mitchell RD (1965) Population regulation of a water mite parasitic on unionid mussels. J Parasitol 51:990-996

Mitchell RD, Pitchford WG (1953) On mites parasitizing Anodonta in England. J Conchol 23:365-370

Paterson RD, Macleod RK (1979) Observation on the life history of the water mite, Unionicola formosa (Acari: Hydrachnellae). Can J Zool 57:2047-2049

Roberts EA, Dimock RV Jr, Forward RB Jr (1978) Positive and host-induced negative phototaxis of the symbiotic water mite Unionicola formosa. Biol Bull (Woods Hole) 155: 599-607

Sokal RR, Rohlf FJ (1981) Biometry. Freeman and Co., San Francisco, CA

Vidrine MF (1980) Systematics and coevolution of unionicolid water-mites and their unionid mussel hosts in the eastern United States. PhD dissertation, University of Southwestern Louisiana, Lafavette, LA

Vidrine MF (1986) Five new species in the subgenus Parasitatax (Acari: Unionicolidae: Unionicola) from North America and Asia with a re-evaluation of related species. Int J Acarol 12:141-153

Vidrine MF (1989) A summary of the mollusk-mite associations of Louisiana and adjacent waters. Environ Prof 6:30-63

Vidrine MF, Clark DR (1993) Freshwater mussel-mite associations in the upper Ouachita River, Montgomery county, Arkansas. Proc LA Acad Sci 56:8-12

Wen CG, Zhu ZM (1999) Seven species of water mites in the genus Unionicola from Jiangxi (Acari: Unionicolidae). Acta Zootaxonomica Sin 24:30-37 (in Chinese with English summary)

Wen CG, Hu BQ, Zhu ZM (1996) Studies on the parasitic ecology of unionicolid mites. J Nanchang Univ (Nat Sci) 20:253-256 (in Chinese with English summary)

Zhang ZG, Ding SF, Xu YM, Wang J (1986) Studies on the mussel Hyriopsis cumingii plague. I. A new viral infectious disease. Acta Microbiol Sin 26:308-312 (in Chinese with English summary)

Submitted: September 6, 2005; Accepted: January 6, 2006

Proofs received from author(s): March 24, 2006 